Tomasz Rokicki

Szkoła Gtówna Gospodarstwa Wiejskiego w Warszawie

\title{
Rynek ubezpieczeniowy w krajach UE
}

\author{
INSURANCE MARKET EU COUNTRIES
}

Celem głównym pracy było rozpoznanie i przedstawienie sytuacji oraz zmian na rynku ubezpieczeniowym $w$ krajach Unii Europejskiej. Badania dotyczyly calego rynku ubezpieczeniowego w UE. Dane dotyczyly lat 2006-2015. Źródła materiałów stanowita analiza dostęnej literatury z zakresu ubezpieczeń, dane z bazy danych Insurance Europe. W pracy wykorzystano metodę porównawcza, postugiwano się wskaźnikami dynamiki, obliczono współczynnik koncentracji Giniego oraz przedstawiono stopień koncentracji za pomocq krzywej Lorenza. Zastosowano również wskaźniki oceniajace rozwój rynku ubezpieczeń. Do prezentacji wyników badań zastosowano metodę opisowa, tabelaryczna i graficznq. Stwierdzono, że na rynku nieznacznie zmniejszyła się liczba działajacych firm $i$ zatrudnionych $w$ nich pracowników. Redukcja zatrudnienia była proporcjonalna. Występowała duża koncentracja tej działalności $w$ kilku najbardziej rozwiniętych krajach UE. W przypadku wartości sktadek przypisanych brutto stopień koncentracji $w$ dominujacych krajach byt jeszcze większy. Dotyczyto to zarówno ubezpieczeń ogólem, jak $i$ ich grup. Sektor ubezpieczeń odczut wpływy pogorszenia koniunktury gospodarczej w 2008 roku, bo w większości krajów nastapit spadek wartości składek ubezpieczeń. $W$ czołowych krajach zmiany w wartości składek nie były gwałtowne. Przy uwzględnieniu zmian w całym okresie 2006-2015 sktadki na ubezpieczenia na życie rosty wolniej niż na pozostałe ubezpieczenia. Taka prawidłowość występowała w przypadku państw generujacych największa wartość składek. Można byto też zauważyć zmiane struktury sktadek na ubezpieczenia, gdyż zmniejszyt się udziat ubezpieczeń an życie z 63,3\% w 2006 roku do 61,5\% w 2015 roku. Rynek ubezpieczeń $w$ UE rozwijat się $w$ wolniejszym tempie niż gospodarka. Świadczy o tym pogarszajacy się wskaźnik penetracji ubezpieczeń. W przypadku tego wskaźnika występowaty widoczne dysproporcje między najbardziej i najmniej rozwiniętymi krajami UE.

Słowa kluczowe: ubezpieczenia, rynek ubezpieczeniowy, Unia Europejska, ubezpieczenia na życie

\section{Wprowadzenie}

Słowo ubezpieczenie jest definiowane różnorodnie. Łazowski [1948] określa je jako urządzenie gospodarcze, które zapewnia pokrycie przyszłych potrzeb majątkowych wywołanych przez odznaczające się pewną prawidłowością zdarzenia losowe. Potrzeby majątkowe są pokrywane przez wiele jednostek, którym te same zdarzenia losowe zagrażają. Banasiński [1997] określa ubezpieczenie jako multiregulator procesów ekonomii rozwoju gospodarki narodowej zakłócanym przez zdarzenia losowe, takie jak klęski żywiołowe, nieszczęśliwe wypadki. Wówczas koszt regulacji zostaje rozłożony bezpośrednio lub pośrednio na z góry określone jednostki (prawne lub fizyczne) korzystające $z$ tego regulatora. Šmid [2012] definiuje ubezpieczenie jako funkcję ekonomiczna, której celem jest wypłata odszkodowań za szkody, zaistniałe w dobrach lub wyrządzone ludziom wskutek np. nieszczęśliwych wypadków. Uzyskanie 
odszkodowania wynika $\mathrm{z}$ umowy, zawieranej pomiędzy ubezpieczycielem a ubezpieczającym. Takie prawo jest nabywane po wniesieniu opłaty, zwanej składką ubezpieczeniową. Ubezpieczenia są więc narzędziami ekonomicznego oddziaływania na rynek [Rokicki 2014, 2016]. Według artykułu 805 Kodeksu Cywilnego przez umowę ubezpieczenia ubezpieczyciel zobowiązuje się, w zakresie działalności swego przedsiębiorstwa, wykonać określone świadczenie w razie zajścia przewidzianego $\mathrm{w}$ umowie wypadku, a ubezpieczający zobowiązuje się zapłacić składkę. Świadczenie ubezpieczyciela oznacza wypłatę przy ubezpieczeniu majątkowym określonego odszkodowania za szkodę powstałą wskutek przewidzianego w umowie wypadku, a przy ubezpieczeniu osobowym wypłatę umówionej sumy pieniężnej, renty lub innego świadczenia w razie zajścia przewidzianego w umowie wypadku w życiu osoby ubezpieczonej [Ustawa... 1964]. Najczęściej stosuje się podział na dwie grupy ubezpieczeń, tj. na życie i inne niż na życie. Przykładowo w Polsce zgodne z tą metodyką są dwa działy. Do działu I są przypisane ubezpieczenia na życie, posagowe i zaopatrzenia dzieci, na życie, jeżeli są związane $\mathrm{z}$ ubezpieczeniowym funduszem kapitałowym, rentowe, wypadkowe i chorobowe, jeśli są uzupełnieniem ubezpieczeń wcześniej wymienionych. W dziale II znajdują się pozostałe ubezpieczenia osobowe i ubezpieczenia majątkowe (NNW i choroby). Zgodnie z polskim prawem, jeden i ten sam ubezpieczyciel nie może jednocześnie oferować klientom ubezpieczeń majątkowych i na życie [Ustawa... 2015; www.piu.org.pl]. W terminologii europejskiej stosuje się podstawowy podział na ubezpieczenia na życie i na grupe pozostałych ubezpieczeń. W przypadku ubezpieczeń innych niż na życie wyróżnia się podgrupy: chorobowe, wypadkowe, komunikacyjne, majątkowe, ogólne OC, morski, lotnicze i transportowe, pozostałe (w tym ochrony prawnej) [

Ubezpieczenia wpływają na rozwój społeczny i gospodarczy na kilka sposobów. Jako instrument, który zawiera ryzyko, prawa ubezpieczeniowe, straty wywoływane przez niekorzystne zdarzenia, powoduje stabilizację funkcjonowania gospodarki. Dodatkowo ubezpieczyciele pomagają zarządzać oszczędnościami i inwestycjami w średnim i długim okresie, przyczyniając się do procesu tworzenia kapitału i przeciwdziałając wahaniom koniunktury gospodarczej. Ubezpieczenia zapewniają więc pewność, dynamikę i efektywność wyników gospodarczych oraz wpływają na wzrost dobrobytu społeczeństwa. Dla rozwoju rynku ubezpieczeń szczególnie ważne są wzrost gospodarczy i dystrybucja dochodów. Istnieją również inne elementy, które mogą je wzmocnić. Innowacyjne podejście polega na dostosowaniu ubezpieczenia do bardzo zróżnicowanych potrzeb i stale zmieniających się społeczeństw. Ważne jest także poszukiwanie nowych i ulepszonych kanałów dystrybucji. Innym stymulującym czynnikiem jest poprawienie edukacji $\mathrm{w}$ zakresie finansów, w tym ubezpieczeń. Możliwe jest również połączenie działań branży ubezpieczeniowej z władzami krajów, poprzez stosowanie zachęt podatkowych, czy też ubezpieczeń obowiązkowych [Insurance..., 2018].

\section{Cele i metodyka badań}

Celem głównym pracy było rozpoznanie i przedstawienie sytuacji oraz zmian na rynku ubezpieczeniowym w krajach Unii Europejskiej. Na potrzeby pracy sformułowano cele szczegółowe, tj. określenie stopnia koncentracji działalności ubezpieczeniowej w 
Unii Europejskiej, ukazanie dynamiki zmian wartości składek w grup ubezpieczeń w krajach UE, określenie związków wartości składek ubezpieczeń ze wzrostem gospodarczym. Badania dotyczyły całego rynku ubezpieczeniowego w UE. Obszar badań wybrano w sposób celowy. Dane dotyczyły lat 2006-2015. Źródła materiałów stanowiła analiza dostępnej literatury $\mathrm{z}$ zakresu ubezpieczeń, dane $\mathrm{z}$ bazy danych Insurance Europe. $\mathrm{W}$ pracy wykorzystano metodę porównawczą, posługiwano się wskaźnikami dynamiki, obliczono współczynnik koncentracji Giniego oraz przedstawiono stopień koncentracji za pomocą krzywej Lorenza. Zastosowano również wskaźniki oceniające rozwój rynku ubezpieczeń. Do prezentacji wyników badań zastosowano metodę opisowa, tabelaryczna i graficzną

\section{Wyniki badań i dyskusja}

Stronę podażową rynku ubezpieczeniowego tworzą firmy działające na rynku wewnętrznym UE. W poszczególnych krajach mogą działać spółki w ramach jednej międzynarodowej firmy. Wówczas traktuje się je jako oddzielne podmioty. W latach 2006-2015 liczba zakładów ubezpieczeń na rynku wewnętrznym w krajach UE zmniejszyła się o $12 \%$ z 3713 do 3259 firm. Jednocześnie nastapiła proporcjonalna redukcja etatów, gdyż liczba pracowników zmniejszyła się z 1032 tys. do 907 tys. Najwięcej zakładów ubezpieczeń było w największych państwach, czyli kolejno w Niemczech (549 w 2015 r.), Wielkiej Brytanii (496), Francji (365). Z kolei najmniej tego typu firm funkcjonowało w najmniejszych krajach, jak na Łotwie (8 zakładów), Malcie (11), w Słowenii i Estonii (po 17). W przypadku liczby etatów najwięcej osób było zatrudnionych w Niemczech (296 tys. w 2015 r.), Francji (147 tys.) i Wielkiej Brytanii (101 tys.), zaś najmniej na Malcie (0,9 tys.), Cyprze 91,4 tys.) i w Estonii (1,5 tys.).

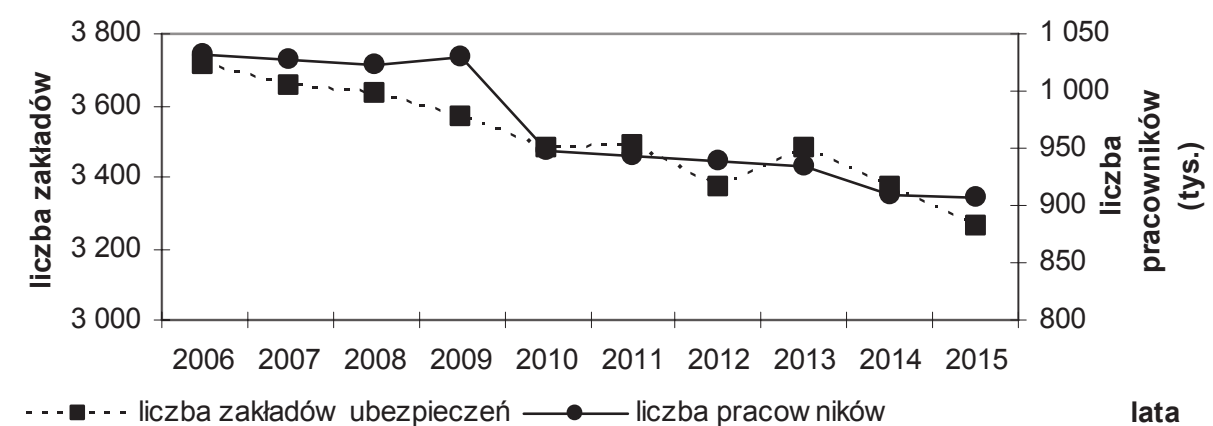

Rysunek 1. Liczba krajowych zakładów ubezpieczeń i zatrudnionych w nich pracowników na rynku wewnętrznym w krajach UE w latach 2006-2015

Źródło: opracowanie własne na podstawie danych Insurance Europe

Do określenia stopnia koncentracji strony podażowej rynku zastosowano współczynnik Giniego. Dane dotyczyły roku 2015, zaś liczba obserwacji wynosiła 28. Współczynnik Giniego obliczony z próby wyniósł 0,56 , zaś estymowany współczynnik dla populacji 0,58. Oznacza to bardzo dużą koncentrację działalności ubezpieczeniowej i zróżnicowanie występujące w UE. Dodatkowo te zróżnicowanie przedstawia krzywa koncentracji Lorenza 
(rys. 2). W 2007 roku współczynniki Giniego były wyższe, bo odpowiednio 0,58 z próby i 0,60 estymowany dla populacji. Oznacza to, że koncentracja działalności ubezpieczeniowej tylko nieznacznie zmniejszyła. Nadal najwięcej firm działało w największych krajach UE. W przypadku liczby pracowników zatrudnionych w zakładach ubezpieczeń występowała jeszcze większa koncentracja, bo dla danych z 2015 roku współczynnik Giniego obliczony z próby wyniósł 0,66 , zaś estymowany współczynnik dla populacji 0,69 . W tym przypadku identyczny poziom koncentracji był w 2006 roku, co oznacza, że struktura działalności ubezpieczeniowej nie podlegała dużym właściwie zmianom.

W przypadku strony popytowej ważna była łączna wartość składek przypisanych brutto. W latach 2006-2015 wzrosła ona we wszystkich krajach UE o 9,5\% z 1020 mld euro do 1117 mld euro. W 2015 roku łączna wartość składek ubezpieczeń była najwyższa w Wielkiej Brytanii (254 mld euro), Francji (206 mld euro) i Niemczech (194 mld euro), zaś najniższa na Litwie i Łotwie (poniżej 0,2 mld euro) oraz w Estonii i Malcie (po 0,4 mld euro). Kolejność w przypadku państw z topu była inna niż przy liczbie zakładów i liczbie zatrudnionych pracowników. Liderem była Wielka Brytania. Współczynnik Giniego obliczony z próby wyniósł 0,76, zaś estymowany współczynnik dla populacji 0,78 . Oznacza to bardzo dużą koncentrację środków finansowych w działalności ubezpieczeniowej i zróżnicowanie występujące w UE. Dodatkowo te zróżnicowanie przedstawia krzywa koncentracji Lorenza (rys. 3). W porównaniu do 2006 roku współczynniki były na identycznym poziomie, co oznacza dużą stabilizację. Podobnie wysoką koncentrację stwierdzono w przypadku ubezpieczeń na życie (life). W 2015 roku współczynnik Giniego obliczony z próby wyniósł 0,77, zaś estymowany współczynnik dla populacji 0,79 . W porównaniu do 2006 roku nastąpiło bardzo małe zmniejszenie koncentracji składek na tego typu ubezpieczenia. W przypadku ubezpieczeń innych niż na życie (non-life) współczynnik Giniego obliczony z próby wyniósł 0,74 , zaś estymowany współczynnik dla populacji 0,77 . W przypadku tej grupy ubezpieczeń nastapił wzrost koncentracji w porównaniu do 2006 roku. Przedstawione wyniki dla składek ubezpieczeń ogółem i jej dwóch grup wskazują na bardzo duża koncentrację środków pieniężnych z tej działalności w kilku krajach UE.

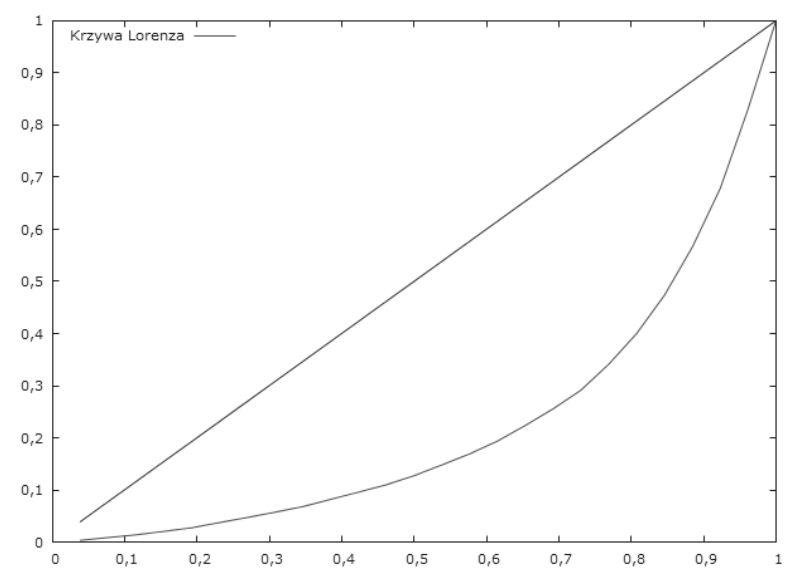

Rysunek 2. Krzywa koncentracji Lorenza dla liczby zakładów ubezpieczeń w krajach UE w 2015 roku Źródło: opracowanie własne na podstawie danych Insurance Europe 

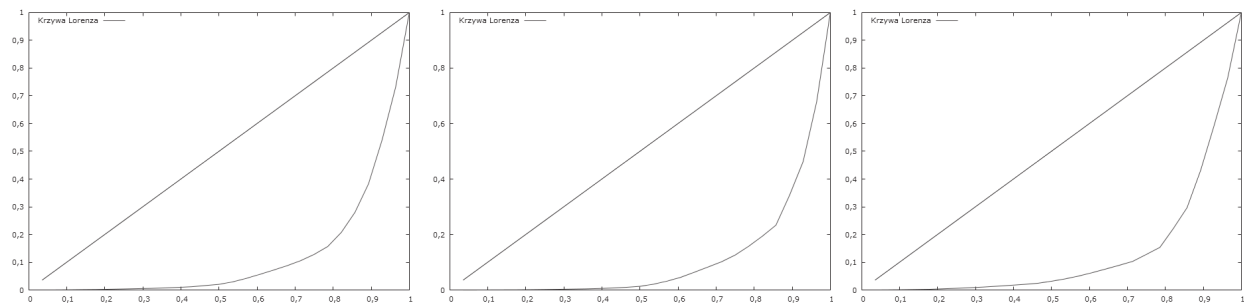

Rysunek 3. Krzywe koncentracji Lorenza dla sumy składek przypisanych brutto w krajach UE w 2015 roku (odpowiednio od lewej dla składek ogółem, dla składek od ubezpieczeń na życie, dla składek od pozostałych ubezpieczeń)

Źródło: opracowanie własne na podstawie danych Insurance Europe

Wartość składek przypisanych brutto ubezpieczeń podlegała wahaniom. W tabeli 1 przedstawiono wskaźniki dynamiki łańcuchowe. Kraje zostały uszeregowane w kolejności malejącej według sumy składek za 2015 rok. Spadki składek brutto ubezpieczeń w większości państw wystapiły w czasie kryzysu gospodarczego w 2008 roku. Największe były na Malcie (spadek o 57\%), Cyprze (o 33\%) oraz Litwie, Łotwie w Wielkiej Brytanii i Irlandii (po ponad 20\%). Poza tym niewielkie spadki odnotowano w latach 2011-2012. Poza 2007 rokiem najkorzystniejszy dla branży był 2014 rok, gdy w większości państw suma składek brutto ubezpieczeń wzrosła znacząco. Sytuację wśród liderów europejskich, poza rokiem kryzysu gospodarczego, była dość stabilna. Nie występowały gwałtowne zmiany. Świadczy to o stabilizacji rynku ubezpieczeń w poszczególnych krajach, jak i całej UE.

Tabela 1. Wskaźniki dynamiki o podstawie zmiennej dla sumy składek przypisanych brutto ubezpieczeń w latach 2007-2015 (rok poprzedni $=100)$

\begin{tabular}{cccccccccc}
\hline \multirow{2}{*}{ Kraj } & \multicolumn{7}{c}{ Wskaźniki dynamiki łańcuchowe w latach 2007-2015 (rok poprzedni=100) } \\
& 2007 & 2008 & 2009 & 2010 & 2011 & 2012 & 2013 & 2014 & 2015 \\
\hline Wielka Brytania & 125,06 & 78,58 & 92,37 & 97,06 & 103,11 & 103,42 & 99,92 & 99,14 & 100,00 \\
Francja & 99,28 & 93,54 & 109,18 & 103,85 & 91,57 & 95,31 & 103,80 & 106,19 & 104,26 \\
Niemcy & 100,62 & 100,98 & 104,19 & 104,32 & 99,61 & 101,97 & 103,19 & 102,77 & 100,62 \\
Włochy & 92,95 & 92,62 & 128,46 & 108,10 & 87,56 & 95,36 & 113,09 & 121,03 & 102,58 \\
Holandia & 101,90 & 104,67 & 98,98 & 100,26 & 101,16 & 95,30 & 100,53 & 97,88 & 97,97 \\
Hiszpania & 103,28 & 109,51 & 102,73 & 93,70 & 105,84 & 94,65 & 97,53 & 98,55 & 101,29 \\
Szwecja & 108,19 & 104,38 & 103,44 & 108,86 & 98,98 & 84,25 & 111,38 & 117,88 & 101,86 \\
Belgia & 106,21 & 93,18 & 96,86 & 103,24 & 99,30 & 110,18 & 85,35 & 100,75 & 97,04 \\
Dania & 110,27 & 106,37 & 97,24 & 106,64 & 105,33 & 103,80 & 100,81 & 93,95 & 104,29 \\
Finlandia & 100,68 & 104,70 & 102,56 & 115,00 & 97,28 & 109,50 & 111,22 & 105,96 & 103,46 \\
Austria & 101,92 & 101,89 & 101,23 & 101,83 & 98,80 & 98,79 & 101,84 & 103,01 & 101,75 \\
Irlandia & 112,35 & 73,63 & 93,28 & 101,60 & 89,76 & 95,61 & 103,67 & 123,89 & 112,86 \\
Portugalia & 100,78 & 113,08 & 92,52 & 113,24 & 70,13 & 94,44 & 121,57 & 108,06 & 88,81 \\
Polska & 117,05 & 134,95 & 86,33 & 105,83 & 104,72 & 109,02 & 92,41 & 94,78 & 98,43 \\
\hline
\end{tabular}




\begin{tabular}{cccccccccc}
\hline Czechy & 106,98 & 104,35 & 104,17 & 110,00 & 98,18 & 98,15 & 101,89 & 100,00 & 96,30 \\
Grecja & 113,64 & 102,00 & 105,88 & 96,30 & 94,23 & 87,76 & 88,37 & 100,00 & 92,11 \\
Luksemburg & 110,00 & 154,55 & 94,12 & 131,25 & 76,19 & 118,75 & 110,53 & 138,10 & 75,86 \\
Węgry & 111,54 & 96,55 & 92,86 & 103,85 & 96,30 & 92,31 & 108,33 & 103,85 & 100,00 \\
Słowacja & 105,56 & 110,53 & 95,24 & 100,00 & 100,00 & 100,00 & 110,00 & 100,00 & 100,00 \\
Słowenia & 111,76 & 105,26 & 105,00 & 100,00 & 95,24 & 100,00 & 95,00 & 100,00 & 100,00 \\
Rumunia & 150,00 & 133,33 & 85,00 & 105,88 & 94,44 & 94,12 & 112,50 & 100,00 & 105,56 \\
Chorwacja & 109,09 & 108,33 & 92,31 & 100,00 & 100,00 & 100,00 & 100,00 & 91,67 & 100,00 \\
Bułgaria & 133,33 & 112,50 & 88,89 & 100,00 & 100,00 & 100,00 & 112,50 & 100,00 & 111,11 \\
Cypr & 109,09 & 66,67 & 100,00 & 100,00 & 112,50 & 88,89 & 87,50 & 100,00 & 100,00 \\
Malta & 116,67 & 42,86 & 100,00 & 100,00 & 100,00 & 100,00 & 100,00 & 133,33 & 100,00 \\
Estonia & 133,33 & 75,00 & 100,00 & 100,00 & 100,00 & 100,00 & 100,00 & 100,00 & 133,33 \\
Łotwa & 133,33 & 125,00 & 60,00 & 100,00 & 100,00 & 133,33 & 100,00 & 50,00 & 100,00 \\
Litwa & 100,00 & 66,67 & 100,00 & 112,50 & 102,22 & 103,26 & 100,00 & 94,74 & 100,00 \\
Razem UE & $\mathbf{1 0 7 , 4 8}$ & $\mathbf{9 2 , 7 1}$ & $\mathbf{1 0 2 , 4 9}$ & $\mathbf{1 0 2 , 3 6}$ & $\mathbf{9 7 , 3 2}$ & $\mathbf{9 9 , 1 7}$ & $\mathbf{1 0 2 , 7 1}$ & $\mathbf{1 0 4 , 3 5}$ & $\mathbf{1 0 1 , 2 6}$ \\
\hline
\end{tabular}

Źródło: opracowanie własne na podstawie danych Insurance Europe

Tabela 2. Wskaźniki dynamiki o podstawie stałej dla sumy składek przypisanych brutto ubezpieczeń w 2015 roku (rok $2006=100)$

\begin{tabular}{|c|c|c|c|}
\hline \multirow{3}{*}{ Kraj } & \multicolumn{3}{|c|}{ Wskaźniki dynamiki o podstawie stałej w 2015 roku (rok 2006 =100) } \\
\hline & \multirow[b]{2}{*}{ ogółem } & \multicolumn{2}{|l|}{ Skladka przypisana brutto } \\
\hline & & dla ubezpieczeń na życie & $\begin{array}{c}\text { dla pozostałych } \\
\text { ubezpieczeń }\end{array}$ \\
\hline Wielka Brytania & 93,08 & 87,40 & 110,71 \\
\hline Francja & 105,60 & 97,21 & 126,81 \\
\hline Niemcy & 119,70 & 118,09 & 121,08 \\
\hline Włochy & 140,13 & 165,56 & 90,14 \\
\hline Holandia & 98,37 & 57,20 & 120,46 \\
\hline Hiszpania & 106,17 & 109,87 & 103,15 \\
\hline Szwecja & 141,81 & 174,36 & 74,03 \\
\hline Belgia & 90,34 & 74,15 & 129,41 \\
\hline Dania & 131,35 & 152,89 & 90,63 \\
\hline Finlandia & 161,49 & 165,25 & 146,67 \\
\hline Austria & 111,54 & 94,44 & 127,38 \\
\hline Irlandia & 97,53 & 86,18 & 136,84 \\
\hline Portugalia & 92,25 & 95,45 & 87,80 \\
\hline Polska & 142,05 & 103,20 & 160,53 \\
\hline Czechy & 120,93 & 140,00 & 110,71 \\
\hline Grecja & 79,55 & 102,00 & 80,95 \\
\hline
\end{tabular}




\begin{tabular}{cccc}
\hline Luksemburg & 220,00 & 260,00 & 180,00 \\
Węgry a & 103,85 & 107,69 & 100,00 \\
Słowacja & 122,22 & 150,00 & 111,11 \\
Słowenia & 111,76 & 100,00 & 116,67 \\
Rumunia & 190,00 & 200,00 & 187,50 \\
Chorwacja & 100,00 & 133,33 & 100,00 \\
Bułgaria & 166,67 & 200,00 & 160,00 \\
Cypr & 63,64 & 60,00 & 66,67 \\
Malta & 66,67 & 75,00 & 50,00 \\
Estonia & 133,33 & 100,00 & 150,00 \\
Łotwa & 66,67 & 68,00 & 65,00 \\
Litwa & 90,00 & 92,00 & 88,00 \\
Razem UE & $\mathbf{1 0 9 , 5 0}$ & $\mathbf{1 0 6 , 5 1}$ & $\mathbf{1 1 4 , 6 5}$ \\
\hline
\end{tabular}

Źródło: opracowanie własne na podstawie danych Insurance Europe

Składki na ubezpieczenia na życie w latach 2006-2015 rosły wolniej niż na pozostałe ubezpieczenia (tab. 2). Taka prawidłowość występowała w przypadku państw generujących największą wartość składek, tj. w Wielkiej Brytanii, Francji i Niemczech. Wśród państw z topu wyjątkiem były Włochy, gdzie wzrost wartości składek ubezpieczeń na życie wyniósł aż $66 \%$, wobec spadku dla pozostałych ubezpieczeń o $10 \%$. Generalnie występowało duże zróżnicowanie pod względem skali wzrostów i spadków. Niemniej można było zauważyć zmianę struktury składek na ubezpieczenia. W 2006 roku składki na ubezpieczenia na życie stanowiły 63,3\% wartości wszystkich ubezpieczeń, a w 2015 roku 61,5\%.

W przypadku ubezpieczeń innych niż na życie można wyróżnić kilka podstawowych ich rodzajów, jak chorobowe, wypadkowe, komunikacyjne, majątkowe, ogólne OC, morskie, lotnicze, pozostałe (w tym ochrony prawnej). W 2006 roku dominowały w tej grupie ubezpieczenia komunikacyjne, które stanowiły 31,53\% wartości składek ogółem (tab. 3). Znaczący był też udział ubezpieczeń chorobowych $(22,54 \%)$ i majątkowych $(19,29 \%)$. Prawie wszystkie $\mathrm{z}$ wymienionych grup były ubezpieczeniami obowiązkowymi. Najmniejsze znaczenie miały ubezpieczenia transportowe, inne niż samochodowe, a więc w transporcie morskim i lotniczym. W 2015 roku struktura uległą zmianie, bo zmniejszyło się znaczenie ubezpieczeń komunikacyjnych na rzecz chorobowych. Odnotowano też wzrost pozostałych ubezpieczeń, w tym związanych z ochrona prawną. Dokonuje się więc stopniowa zmiana struktury, gdyż zyskują na znaczeniu ubezpieczenia, które wcześniej miały marginalne znaczenie. 
Tabela 3. Struktura wartości składek przypisanych brutto ubezpieczeń innych niż na życie w latach 2006-2015

\begin{tabular}{|c|c|c|c|c|c|c|c|c|c|c|}
\hline \multirow{2}{*}{ Kraj } & \multicolumn{6}{|c|}{ Udzial składek na poszczególne ubezpieczenia w wartości ogółem w latach (\%) } \\
\cline { 2 - 12 } & $\mathbf{2 0 0 6}$ & $\mathbf{2 0 0 7}$ & $\mathbf{2 0 0 8}$ & $\mathbf{2 0 0 9}$ & $\mathbf{2 0 1 0}$ & $\mathbf{2 0 1 1}$ & $\mathbf{2 0 1 2}$ & $\mathbf{2 0 1 3}$ & $\mathbf{2 0 1 4}$ & $\mathbf{2 0 1 5}$ \\
\hline chorobowe & 22,54 & 22,96 & 23,69 & 24,33 & 24,80 & 25,37 & 25,16 & 25,80 & 26,30 & 25,80 \\
\hline wypadkowe & 7,44 & 7,50 & 7,53 & 7,42 & 7,41 & 7,34 & 7,23 & 7,31 & 7,21 & 7,22 \\
\hline komunikacyjne & 31,53 & 31,22 & 30,35 & 29,59 & 29,10 & 29,36 & 29,37 & 29,03 & 28,12 & 28,05 \\
\hline majątkowe & 19,29 & 19,26 & 19,42 & 19,67 & 19,50 & 19,46 & 19,89 & 19,94 & 19,67 & 19,67 \\
\hline ogólna OC & 8,75 & 8,65 & 8,83 & 8,74 & 8,10 & 7,89 & 8,00 & 7,40 & 7,50 & 7,42 \\
\hline morskie, lotnicze & 3,92 & 3,90 & 3,90 & 4,35 & 4,47 & 4,41 & 4,25 & 3,95 & 3,98 & 3,95 \\
\hline $\begin{array}{l}\text { pozostałe (w tym } \\
\text { ochrony prawnej }\end{array}$ & 6,53 & 6,51 & 6,28 & 5,90 & 6,62 & 6,17 & 6,10 & 6,57 & 7,22 & 7,89 \\
\hline
\end{tabular}

Źródło: opracowanie własne na podstawie danych Insurance Europe

Do oceny rozwoju rynku ubezpieczeniowego służy także wskaźnik penetracji ubezpieczeń określany jako relacja składki przypisanej brutto do produktu krajowego brutto (PKB). W 2015 roku średni wskaźnik dla UE wyniósł 7,6\%, w tym na ubezpieczenia na życie 4,7\% i pozostałe $2,9 \%$. W 2006 roku łączna wartość składek brutto stanowiła $9 \%$ PKB, w tym na ubezpieczenia na życie 5,7\% i pozostałe $3,3 \%$. Wskaźnik ten uległ pogorszeniu, co oznacza, że rynek ubezpieczeniowy w UE rozwijał się wolniej niż wzrastała wartość PKB. W 2015 roku najwyższy wskaźnik penetracji ubezpieczeń był w Finlandii (11,4\% dla ubezpieczeń ogółem, w tym na życie 9,3\% i pozostałe 2,1\%). Wskaźnik poniżej 2\% odnotowano na Łotwie, w Rumunii, Estonii i Grecji. Otrzymane wyniki świadczą o dużym zróżnicowaniu rynku ubezpieczeń w Unii Europejskiej.

Literatura dotycząca rynku ubezpieczeń w UE jest dosyć uboga. Według badań Fenna i jego zespołu [2008] w latach 1995-2001 na efektywność działania firm miała wpływ ich wielkość. Te większe i z dużym udziałem w rynku były mniej efektywne. Wówczas firmy działały w warunkach malejących kosztów i rosnących zysków. Podobne wyniki uzyskali Kasman Turgutlu [2011]. Według nich wszystkie systemy ubezpieczeniowe wykazują znaczny poziom nieefektywności kosztowej, a korzyści skali dotyczą małych i średnich firm ubezpieczeniowych. Wyniki były podobne dla krajów UE-15 i przyjętych po akcesji w 2004 roku. Ponadto autorzy stwierdzili, że procesy deregulacji i liberalizacji zmierzające do utworzenia jednolitego europejskiego rynku finansowego miały też duży wpływ na branżę ubezpieczeniową. Taką tezę potwierdziły badania Barrosa, Nektariosa i Assafa [2010], którzy na przykładzie rynku greckiego stwierdzili, że deregulacja wpłynęła na efektywność sektora ubezpieczeń. Konkurencja o udziały w rynku była główną przyczyną większej efektywności greckiego sektora ubezpieczeń. Klein [2013] w swojej książce podkreślił, że na rynek ubezpieczeniowy oprócz konkurencji wpływają ryzyko katastrof i ryzyko systemowe. Pierwsze ryzyko jest trudne do przewidzenia i przeciwdziałania.

Haiss i Sümegi [2008] w swoich badaniach podkreślali związek ubezpieczeń ze wzrostem PKB. Taką relację $\mathrm{w}$ odniesieniu do ubezpieczeń na życie stwierdzono w krajach UE-15 oraz w Szwajcarii, Norwegii i Islandii. W krajach Europy Środkowej i 
Wschodniej tego typu zależności były widoczne w przypadku ubezpieczeń odpowiedzialności cywilnej. W badaniach stwierdzono też wpływ realnej stopy procentowej i poziomu rozwoju gospodarczego na wzrost ubezpieczeń. Zależności między PKB a ubezpieczeniami potwierdzają badania Ćuraka, Lončara i Poposkiego [2009], którzy badali zależności w 10 państwach członkowskich UE w latach 19922007. Według autorów rozwój sektora ubezpieczeń wpływał znacząco na wzrost gospodarczy. Dotyczyło to zarówno ubezpieczeń na życie, jak i innych niż na życie, a także ubezpieczeń całkowitych.

\section{Podsumowanie}

Rynek ubezpieczeniowy w Unii Europejskiej charakteryzowany przez stronę podażową nie podlegał gwałtownym zmianom. Liczba firm działających na rynku wewnętrznym zmniejszyła się, podobnie proporcjonalnie zatrudnionych było mniej pracowników. Świadczy to o powolnych zmianach strukturalnych. Firmy były skoncentrowane w największych państwach o dużym potencjale gospodarczym, jak Niemcy, Wielka Brytania i Francja. W latach 2006-2015 poziom koncentracji działalności ubezpieczeniowej został utrzymany na wysokim poziomie.

W latach 2006-2015 o 9,5\% wzrosła łączna wartość składek przypisanych brutto w UE. Podobnie jak w przypadku podaży, wpływy ze składek były skoncentrowane w kilku krajach, tj. Wielkiej Brytanii, Niemczech i Francji. Współczynnik Giniego obliczony z próby wyniósł 0,76 , co oznacza bardzo dużą koncentrację wartości składek z ubezpieczeń w kilku krajach UE. W przypadku podziału ubezpieczeń na dwa działy, czyli ubezpieczenia na życie i inne niż na życie (pozostałe) stwierdzono, że koncentracja była bardzo wysoka. Zwiększała się ona w przypadku ubezpieczeń innych niż na życie.

Sektor ubezpieczeń odczuł wpływy pogorszenia koniunktury gospodarczej w 2008 roku, bo w większości krajów nastąpił spadek wartości składek ubezpieczeń. Trudne były tez lata 2011-2012. W pozostałych latach sytuacja była stabilna. W czołowych krajach zmiany w wartości składek nie były gwałtowne. W pozostałych krajach zdarzały się okresy dużych wzrostów lub spadków składek w danym roku.

Przy uwzględnieniu zmian w całym okresie 2006-2015 składki na ubezpieczenia na życie rosły wolniej niż na pozostałe ubezpieczenia. Taka prawidłowość występowała w przypadku państw generujących największą wartość składek. Można było też zauważyć zmianę struktury składek na ubezpieczenia, gdyż zmniejszył się udział ubezpieczeń an życie z 63,3\% w 2006 roku do 61,5\% w 2015 roku. W przypadku ubezpieczeń innych niż na życie zmniejszyło się znaczenie ubezpieczeń komunikacyjnych na rzecz chorobowych. Odnotowano też wzrost pozostałych ubezpieczeń, w tym związanych z ochrona prawną. Dokonuje się więc stopniowa zmiana struktury, gdyż zyskują na znaczeniu ubezpieczenia, które wcześniej miały marginalne znaczenie.

Rynek ubezpieczeń w UE rozwijał się w wolniejszym tempie niż gospodarka. Świadczy o tym pogarszający się wskaźnik penetracji ubezpieczeń. W przypadku tego wskaźnika występowały widoczne dysproporcje między najbardziej i najmniej rozwiniętymi krajami UE. Przedstawiony przegląd literatury potwierdził te różnice. W nielicznych badaniach potwierdzono związek wzrostu ubezpieczeń ze wzrostem gospodarczym. Dodatkowo badacze twierdzili, że rynek ubezpieczeniowy podlega dużej konkurencji, co przyczynia się do większej efektywności działających na nim firm.. 


\section{Literatura}

Banasiński A.: Ubezpieczania gospodarcze, POLTEXT, Warszawa 1997.

Barros C.P., Nektarios M., Assaf, A.: Efficiency in the Greek insurance industry, European Journal of Operational Research, 205(2), 2010, pp. 431-436.

Ćurak M., Lončar S., Poposki K.: Insurance sector development and economic growth in transition countries, International Research Journal of Finance and Economics, 34(3), 2009, pp. 29-41.

Fenn P., Vencappa D., Diacon S., Klumpes P., O'Brien, C.: Market structure and the efficiency of European insurance companies: A stochastic frontier analysis, Journal of Banking \& Finance, 32(1), 2008, pp. 86-100.

Haiss P., Sümegi, K.: The relationship between insurance and economic growth in Europe: a theoretical and empirical analysis, Empirica, 35(4), 2008, pp. 405-431.

Insurance Europe Annual Report 2017-2018, Insurance Europe, Brussels 2018, s. 6-8.

Kasman A., Turgutlu E.: Performance of European insurance firms in the single insurance market, International Review of Applied Economics, 25(3), 2011, pp. 363-378.

Klein R.W.: Insurance market regulation: Catastrophe risk, competition, and systemic risk, In Handbook of insurance, Springer, New York 2013, pp. 909-939.

Łazowski J.: Wstęp do nauki o ubezpieczeniach, W. Mogilski (red.), PZUW, Warszawa 1948.

Rokicki T.: Organizacja i ekonomika transportu, Wydawnictwo SGGW, Warszawa 2014, s. 61.

Rokicki T.: Ekonomiczno-organizacyjne uwarunkowania towarowego rynku usług transportowych, Wydawnictwo SGGW, Warszawa 2016, s. 40-41.

Šmid W.:Boss leksykon, Wydawnictwo Dr Lex, Kraków 2012.

Ustawa z dnia 23 kwietnia 1964 r. Kodeks cywilny, Dz. U. z 2014 r. poz. 121, 827, z 2015 r. poz. 4, 397, 539 .

Ustawa z dnia 11 września 2015 r. o działalności ubezpieczeniowej i reasekuracyjnej, Dz. U. z 2017 r. poz. 1170, 1089, 1926, 2102.

www.piu.org.pl, strona internetowa Polskiej Izby ubezpieczeń (dostęp 05.01.2018).

\section{Summary}

The aim of the work was to recognize and present the situation and changes on the insurance market in the European Union. The research concerned the entire insurance market in the EU. The data concerned the years 2006-2015. Sources of materials were the analysis of available literature in the field of insurance, data from the Insurance Europe database. The work uses the comparative method, the dynamics indexes were used, the Gini concentration coefficient was calculated and the degree of concentration was presented using the Lorenzo curve. Indicators assessing the development of the insurance market were also applied. The descriptive, tabular and graphical methods were used to present the results of the research. It was found, that the number of operating companies and their employees slightly decreased on the market. Employment reduction was proportional. There was a large concentration of this activity in several of the most developed EU countries. In the case of gross written premiums, the concentration level in the dominant countries was even greater. This concerned both total insurance and their groups. The insurance sector experienced the impact of the economic downturn in 2008, as in most countries the value of insurance premiums decreased. In top countries, changes in the value of premiums were not rapid. Taking into account changes throughout the period 2006-2015, life insurance premiums grew more slowly than for other insurance. Such regularity occurred in the case of countries generating the highest value of premiums. It was also possible to notice a change in the structure of insurance premiums, as the share of life insurance went down from $63.3 \%$ in 2006 to $61.5 \%$ in 2015 . The insurance market in the EU has been growing at a slower pace than the economy. This is evidenced by the deteriorating insurance penetration rate. In the case of this indicator, there were visible disproportions between the most and least developed EU countries. 
Key words: insurance, insurance market, European Union, life insurance

Informacje o autorze:

Dr hab. inż. Tomasz Rokicki

Szkoła Głowna Gospodarstwa Wiejskiego w Warszawie

Wydział Nauk Ekonomicznych

Katedra Logistyki

Ul. Nowoursynowska 166

02-787 Warszawa

e-mail: tomasz rokicki@sggw.pl

ORCID: 0000-0003-3356-2643 